\title{
Front Matter: Volume 10170
}

, "Front Matter: Volume 10170," Proc. SPIE 10170, Health Monitoring of Structural and Biological Systems 2017, 1017001 (1 June 2017); doi: $10.1117 / 12.2279840$

Event: SPIE Smart Structures and Materials + Nondestructive Evaluation and Health Monitoring, 2017, Portland, Oregon, United States 


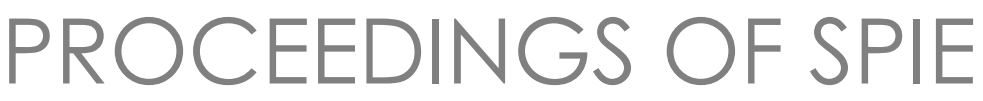

\section{Health Monitoring of Structural and Biological Systems 2017}

\section{Tribikram Kundu}

Editor

\section{6-29 March 2017 \\ Portland, Oregon, United States}

Sponsored by

SPIE

Co-sponsored by

OZ Optics, Ltd. (United States)

Polytec, Inc. (United States)

Fiberguide Industries (United States)

Frontiers Media (Switzerland)

Cooperating Organizations

Jet Propulsion Laboratory (United States)

Published by

SPIE 
The papers in this volume were part of the technical conference cited on the cover and title page. Papers were selected and subject to review by the editors and conference program committee. Some conference presentations may not be available for publication. Additional papers and presentation recordings may be available online in the SPIE Digital Library at SPIEDigitallibrary.org.

The papers reflect the work and thoughts of the authors and are published herein as submitted. The publisher is not responsible for the validity of the information or for any outcomes resulting from reliance thereon.

Please use the following format to cite material from these proceedings:

Author(s), "Title of Paper," in Health Monitoring of Structural and Biological Systems 2017, edited by Tribikram Kundu, Proceedings of SPIE Vol. 10170 (SPIE, Bellingham, WA, 2017) Seven-digit Article CID Number.

ISSN: 0277-786X

ISSN: 1996-756X (electronic)

ISBN: 9781510608252

ISBN: 9781510608269 (electronic)

Published by

SPIE

P.O. Box 10, Bellingham, Washington 98227-0010 USA

Telephone +1 3606763290 (Pacific Time) · Fax +1 3606471445

SPIE.org

Copyright (c) 2017, Society of Photo-Optical Instrumentation Engineers.

Copying of material in this book for internal or personal use, or for the internal or personal use of specific clients, beyond the fair use provisions granted by the U.S. Copyright Law is authorized by SPIE subject to payment of copying fees. The Transactional Reporting Service base fee for this volume is $\$ 18.00$ per article (or portion thereof), which should be paid directly to the Copyright Clearance Center (CCC), 222 Rosewood Drive, Danvers, MA 01923. Payment may also be made electronically through CCC Online at copyright.com. Other copying for republication, resale, advertising or promotion, or any form of systematic or multiple reproduction of any material in this book is prohibited except with permission in writing from the publisher. The CCC fee code is 0277-786X/17/\$18.00.

Printed in the United States of America.

Publication of record for individual papers is online in the SPIE Digital Library.

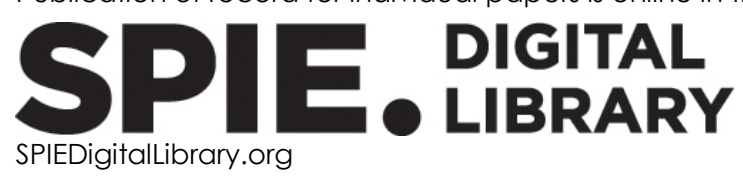

Paper Numbering: Proceedings of SPIE follow an e-First publication model. A unique citation identifier (CID) number is assigned to each article at the time of publication. Utilization of CIDs allows articles to be fully citable as soon as they are published online, and connects the same identifier to all online and print versions of the publication. SPIE uses a seven-digit CID article numbering system structured as follows:

- The first five digits correspond to the SPIE volume number.

- The last two digits indicate publication order within the volume using a Base 36 numbering system employing both numerals and letters. These two-number sets start with 00, 01, 02, 03, 04, $05,06,07,08,09,0 A, 0 B \ldots$. OZ, followed by 10-1Z, 20-2Z, etc. The CID Number appears on each page of the manuscript. 


\title{
Contents
}

\author{
ix Authors \\ xiii Conference Committee \\ xvii Introduction
}

PLENARY SESSION

1017002 Predictive simulation of guide-wave structural health monitoring (Plenary Paper)

[10170-500]

\section{SESSION 1 COMPOSITE MONITORING I}

1017004 Infrared thermography to impact damaging of composite materials [10170-2]

1017005 Assessment of delamination in composite beam using infrared thermography, optical sensors and terahertz technique [10170-3]

1017006 Shear sensing in bonded composites with cantilever beam microsensors and dual-plane digital image correlation [10170-4]

\section{SESSION 2 COMPOSITE MONITORING II}

1017007 Full-field ultrasonic inspection for a composite sandwich plate skin-core debonding detection using laser-based ultrasonics [10170-5]

1017008 Assessment of damage in 'green' composites [10170-6]

1017009 A constructive nonlinear array (CNA) method for barely visible impact detection in composite materials [10170-7]

$10170 \mathrm{OB}$ Evaluation of adhesively bonded composites by nondestructive techniques [10170-9]

\section{SESSION 3 METAMATERIAL I}

10170 OF A disorder-based strategy for tunable, broadband wave attenuation [10170-13]

10170 0J Simultaneous life extension and crack monitoring of fatigue-damaged steel members using multifunctional carbon nanotube based composites [10170-128] 
10170 OM Isotropic transformation acoustics and applications [10170-20]

SESSION 5 ADVANCEMENTS IN MODELING

1017000 Parametric studies for semi-analytical investigation of plate-mounted resonators [10170-22]

10170 OP Application of distributed point source method (DPSM) to wave propagation in anisotropic media [10170-23]

$101700 Q \quad$ Computational wave field modeling in anisotropic plate [10170-24]

10170 OR Optimization of multi-scale modelling of CNT/polymer composite strain sensors [10170-25]

SESSION 6 BIOINSPIRED SHM AND BIOMATERIAL MONITORING

10170 OT Dual-frequency transducer with a wideband PVDF receiver for contrast-enhanced, adjustable harmonic imaging [10170-27]

10170 OV Development of an aerosol PZT actuator for a scanner system [10170-29]

10170 OW Design, analysis, and fabrication of a piezoelectric force plate [10170-30]

$101700 Z$ Development and testing of a multi-transducer system for measuring height of condensed water in steam pipes with steady-state and turbulent flow conditions [10170-35]

\section{SESSION 7 REAL-TIME SENSING AND TESTING AT EXTREME ENVIRONMENTS}

$1017012 \quad$ NIR intensity sensor for water pressure monitoring [10170-36]

1017014 Development of BS-PT based high temperature ultrasonic transducer [10170-38]

1017016 Signal denoising using stochastic resonance and bistable circuit for acoustic emission-based structural health monitoring [10170-17]

\section{SESSION 8A METAMATERIAL III}

1017018 A mechanical power dissipation model for axially loaded metamaterial bars [10170-41]

$101701 \mathrm{~A} \quad$ Nonlinear dynamics of bistable lattices with defects [10170-43] 
10170 1B Ultrasonic damage imaging of structural components with bulk and guided waves using match coefficients [10170-44]

$101701 \mathrm{C}$ Nondestructive assessment of waveguides using an integrated electromechanical impedance and ultrasonic waves approach [10170-45]

10170 1D Guided wave attenuation in composite materials [10170-46]

10170 1E Guided waves based SHM systems: parameters selection for better identification and localisation of damages in composites stiffened plates [10170-47]

\section{SESSION 9A METAMATERIAL IV}

$10170 \mathrm{lF}$ An analytical model for band gap behavior in lumped elastic metamaterials [10170-48]

1017011 Acoustic vortex beam generation using a compact metamaterial aperture [10170-51]

$101701 \mathrm{~J}$ Analyzing the frequency band gap in functionally graded materials with harmonically varying material properties [10170-52]

$101701 \mathrm{~K}$ Scattering of longitudinal acoustic phonons in thin silicon membranes [10170-53]

10170 IL Smart Kirigami open honeycombs in shape changing actuation and dynamics [10170-54]

SESSION 9B GUIDED WAVES II: MEASUREMENT, DAMAGE DETECTION, AND SCATTERING

$101701 \mathrm{~N}$ Directionality of Ao Lamb wave mode scattering at defects [10170-56]

1017010 Guided wave scattering by a geometrical or damage feature: application to fatigue crack and machined notch [10170-57]

$101701 Q \quad$ Lamb wave interaction at debondings due to impact damage in complex stiffened CFRP structures [10170-59]

10170 is Laser Doppler velocimetry and PZT sensing for the study of guided waves in a stepped aluminum plate [10170-61]

$101701 \mathrm{U} \quad$ Nonlinear dispersion effects in elastic plates: numerical modelling and validation [10170-63]

\section{SESSION 10A NONLINEAR TECHNIQUES}

$101701 \mathrm{~A}$ A three-dimensional analytical model for interpreting contact acoustic nonlinearity generated by a "breathing" crack [10170-66]

10170 1Y Fatigue crack detection by nonlinear spectral correlation with a wideband input [10170-67] 
1017012 Numerical investigation of nonlinear interactions between multimodal guided waves and delamination in composite structures [10170-68]

1017020 Analysis of debonding in single lap joints based on employment of ultrasounds [10170-69]

\section{SESSION 1OB MODELING FOR METAMATERIAL AND GUIDED WAVES}

1017021 Spectral element method implementation on GPU for Lamb wave simulation [10170-70]

1017022 On the assumption of transverse isotropy of a honeycomb sandwich panel for NDT applications [10170-71]

1017023 Local numerical modelling of ultrasonic guided waves in linear and nonlinear media [10170-72]

1017024 Coupled electromechanical modeling of piezoelectric disc transducers for low-frequency ultrasonic collimated beam generation [10170-73]

\section{SESSION 11A ACOUSTIC EMISSION}

1017027 Reflective SOA-based fiber Bragg grating ultrasonic sensing system with two wave mixing interferometric demodulation [10170-76]

1017028 Acoustic emission source modeling in a plate using buried moment tensors [10170-77]

1017029 Probabilistic location estimation of acoustic emission sources in isotropic plates with one sensor [10170-78]

$101702 \mathrm{~A}$ Analysis of acoustic emission waveforms from fatigue cracks [10170-79]

SESSION 11B GUIDED WAVES III: ADVANCED MATERIAL MONITORING

$101702 B \quad$ High frequency guided wave propagation in monocrystalline silicon wafers [10170-80]

$101702 \mathrm{D}$ Combined vibration and guided wave-based approach for composite panels health assessment [10170-82]

$101702 \mathrm{E} \quad$ Numerical modeling of the load effect on PZT-induced guided wave for load compensation of damage detection [10170-83]

SESSION 12A CIVIL INFRASTRUCTURE I: MEASUREMENT OPTIMIZATION AND APPLICATION

$101702 \mathrm{~F}$ Optimal sensor placement for parameter estimation of bridges [10170-92]

101702 A An application of prospect theory to a SHM-based decision problem [10170-84]

vi 
$101702 \mathrm{H} \quad$ Structural damage identification with multi-objective DIRECT algorithm using natural frequencies and single mode shape [10170-85]

1017021 Monitoring progressive changes in cementitious materials using embedded piezo-sensors [10170-87]

SESSION 12B OPTICAL AND THERMAL TECHNIQUES FOR CIVIL INFRASTRUCTURE MONITORING

$101702 \mathrm{~K}$ Application of the normalized curvature ratio to an in-service structure [10170-89]

$101702 \mathrm{~L}$ Effect of out-of-plane specimen movement on the accuracy of the smallest specimen strain measurable using the digital image correlation technique [10170-90]

$101702 \mathrm{M}$ Uncertainty quantification of phase-based motion estimation on noisy sequence of images [10170-91]

$101702 \mathrm{~N}$ Study on evaluation of corrosion condition of reinforcing bar embedded concrete using infrared thermal imaging camera [10170-93]

\section{SESSION 13A CIVIL INFRASTRUCTURE II: MATERIALS AND STRUCTURES}

$101702 \mathrm{P} \quad$ Monitoring of prestress losses using long-gauge fiber optic sensors [10170-95]

$101702 Q \quad$ System identification of timber masonry walls using shaking table test [10170-96]

$101702 \mathrm{R}$ Abnormal behavior detection algorithm of infra-structure using unfamiliarity index [10170-98]

1017025 Comparison of two novel types of sensor to monitor the strain of concrete in F-T tests [10170-99]

$101702 \mathrm{U}$ Development of a real-time bridge structural monitoring and warning system: a case study in Thailand [10170-101]

$101702 \mathrm{~V}$ Experimental validation of a structural damage detection method based on marginal Hilbert spectrum [10170-102]

\section{SESSION 13B EMERGING AND FUTURISTIC TECHNIQUES AND ISSUES}

$101702 \mathrm{~W}$ Moisture contamination detection in adhesive layer using embedded fibre Bragg grating sensors [10170-103]

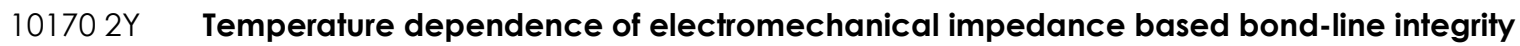
monitoring [10170-105]

$101702 Z$ A load identification sensor based on distributed fiber optic technology [10170-106] 
1017032 Fatigue crack monitoring of aerospace structure based on binary tree support vector machines [10170-110]

1017033 Non-destructive monitoring of a prestressed bridge with a data-driven method [10170-111]

$1017034 \quad$ Nuclear power plant prestressed concrete containment vessel structure monitoring during integrated leakage rate test using three kinds of fiber optic sensors [10170-112]

1017037 A novel nonlinear damage resonance intermodulation effect for structural health monitoring [10170-115]

1017038 Numerical simulation on the temperature behavior of the main cable for suspension bridge [10170-116]

1017039 Damage estimation of sewer pipe using subtitles of CCTV inspection video [10170-117]

10170 3A Monitoring of impact dynamics on carbon nanotube multiscale glass fiber composites by means of electrical measurements [10170-118]

10170 3B A comparative study on book shelf structure based on different domain modal analysis [10170-119]

10170 3E Performance assessment of engineering structures based on long-gauge FBG sensors: a review [10170-122]

10170 3G Automated vehicle counting using image processing and machine learning [10170-124]

$101703 \mathrm{H} \quad$ Using LabView for real-time monitoring and tracking of multiple biological objects [10170-125] 


\section{Authors}

Numbers in the index correspond to the last two digits of the seven-digit citation identifier (CID) article numbering system used in Proceedings of SPIE. The first five digits reflect the volume number. Base 36 numbering is employed for the last two digits and indicates the order of articles within the volume. Numbers start with 00, 01, 02, 03, 04, 05, 06, 07, 08, 09, OA, OB...0Z, followed by 10-12, 20-2Z, etc.

\author{
Abdel-Jaber, Hiba, 2P \\ Ahmed, Shafique, $0 \mathrm{~J}$ \\ Al Ba'ba'a, H., 18, $1 \mathrm{~F}$ \\ Ameduri, S., $2 Z$ \\ Ansari, M.h., $1 \mathrm{~J}$ \\ Anton, Steven R., OW \\ Arrieta, Andres F., IA \\ Bach, M., $1 Q$ \\ Badescu, Mircea, $\mathrm{OZ}$ \\ Bagchi, Ashutosh, 2Q, 2V, 3B \\ Banerjee, S., OQ \\ Banerii, Srishti, 2V \\ Bao, Jingjing, 2A \\ Bar-Cohen, Yoseph, $0 Z$ \\ Baur, Jeffery W., 06 \\ Berthe, Laurent, 08 \\ Bettini, P., $2 Z$ \\ Bhuiyan, Md. Yeasin, 28, 2A \\ Bilgunde, Prathamesh, 14, 2 Y \\ Bilodeau, Maxime, 10 \\ Bilynsky, Yosyp Y., 3H \\ Blacha, Izabela, OR \\ Boccardi, Simone, 04 \\ Boffa, Natalino D., 04, 1E, is \\ Bolognani, Denise, $2 G$ \\ Bond, Leonard J., 14, $2 Y$ \\ Bonilla Mora, Veronica, $2 \mathrm{~W}$ \\ Bouslama, Nidhal, 10 \\ Boustie, Michel, 08 \\ Calvo, David C., 11 \\ Cao, Maosen, 2D \\ Cao, Pei, $2 \mathrm{H}$ \\ Cappello, Carlo, $2 \mathrm{G}$ \\ Cardella, Davide, OF \\ Carlomagno, Giovanni M., 04 \\ Celli, Paolo, OF \\ Cervantes, William, $0 Z$ \\ Chen, Lan, 38 \\ Chen, Ling-Chih, 12 \\ Chen, Peng-Jyun, OV \\ Chen, Shizhi, 3E \\ Chillara, Vamshi Krishna, 24 \\ Chocinski-Arnault, Laurence, 08 \\ Chong, See Yenn, 07 \\ Ciampa, Francesco, 37 \\ Ciminello, M., $2 Z$ \\ Cinquemani, Simone, 3A \\ Concilio, A., $2 Z$ \\ Dayton, Paul A., OT
}

Desai, Niranjan, $2 \mathrm{~L}$

de Vasconcellos, Davi, 08

Ding, Yanbing, $2 S$

Ebrahimkhanlou, Arvin, 29

Ecault, Romain, OB

Eckstein, B., 1Q

Eskew, Edward, 2F, 3G

Fooladi, Samaneh, OP

Fritzen, C.-P., 1Q

Fromme, Paul, 1N, 2B

Gelda, Dhruv, 1K

Ghossoub, Marc G., 1K

Giurgiutiu, Victor, 02, 28, 2A

Glisic, Branko, 2G, 2K, 2P

Gonella, Stefano, OF

Grabowski, Krzysztof, OR

Güemes, Alfredo, 3A

Guerreiro, Luis, 2Q

Guild, Matthew D., 11

Harne, Ryan L., 16

Hong, Wan, 3E

Hoummadi, Elias, OW

Huang, Zhiguang, 38

Hwang, Myungwon, 1A

Jang, Shinae, 2F, 3G

Jiang, Xiaoning, OT

Jiménez-Suárez, Alberto, 3A

Joseph, Roshan, 28

Karami, M. Amin, $1 \mathrm{~J}$

Khemapech, I., 2 U

Kijanka, Piotr, 1U, 23

Kim, Byeongcheol, 2R, 39

Kim, Jinki, 16

Kim, Jinwook, OT

Kim, Taeheon, 2R, 39

Kliewer, Kaitlyn, 2K

Kocherla, Amarteja, 2

Kondash, Corey, 06

Kong, Xianglong, 2S, 34

Krasilenko, Vladimir G., 3H

Krishnaswamy, Sridhar, 27

Kudela, Pawel, 1D, 21, 2D

Kundu, Tribikram, OP

Lanza di Scalea, F., 1B

Leamy, Michael J., 1U, 23

Lee, Hyeong Jae, 0 Z

Leng, J., IL

Li, Jinke, 34

Li, Shengyuan, $2 S$ 
Li, Sibo, OT

Liang, Chunfang, 38

Liao, Kaixing, 2S, 34

Lih, Shyh-Shiuh, OZ

Limongelli, M. P., 33

Lin, Ting-Kai, OV

Lindsey, Brooks D., OT

Liu, Peipei, IY

Lu, Shenbo, 32

LV, Haifeng, $2 S$

Ma, Zhaoyun, 1C

Maio, L., 1E, 1S

Majewska, Katarzyna, 05

Mal, Ajit K., 00, 1S, 22

Malfense Fierro, Gian Piero, 09

Malinowski, Paweł H., 08, OB, ID

Mao, Zhu, 2M

Martin, Theodore P. 11

Martinez-Castro, Rosana, $3 G$

Maslouhi, Ahmed, 10

Masserey, Bernard, 2B

Masson, Patrice, 10

McConnell, Jennifer, 0J

M'Closkey, Robert, 00

Meany, Sean, 3G

Memmolo, V., 1E, 1S

Meo, Michele, 09, 37

Meola, Carosena, 04

Micheau, Philippe, 10

Mieloszyk, Magdalena, 05, 2W

Moix Bonet, M., $1 Q$

Monaco, E., 1E, 1S

Montanini, R., 1B

Naify, Christina J., 11

Narayanan, Arun, 2l

Nasrollahi, Amir, 1C

Neville, R. M., $1 \mathrm{~L}$

Nicassio, F., 20

Nicoli, S., $2 Z$

Nikolskyy, Aleksandr I., 3H

Norris, Andrew N., OM

Nouh, M., 18, $1 \mathrm{~F}$

Orris, Gregory J., 11

Ostachowicz, Wiesław M., 05, 08, 0B, 1D, 21, 2D, 2W

Packo, Pawel, OR, 1U, 23

Pantea, Cristian, 24

Park, Kitae, 2R, 39

Pascual Gonzalez, Pedro, 08

Pizzolato, Marco, 2B

Poddar, Banibrata, 2A

Poling, Joel, 2L

Qing, Xinlin P., 2E

Quaegebeur, Nicolas, 10

Quattrocchi, A., 1B

Radecki, Rafal, 1U, 23

Radzienski, Maciej, 21, 2D

Rajagopal, Manjunath C., $1 \mathrm{~K}$

Ricci, Fabrizio, 04, 1E, $1 \mathrm{~S}$

Rizzo, Piervincenzo, 1C
Robyr, Jean-Luc, 2B

Rogers, Jeffrey S., 11

Rohde, Charles A., 11

Roy, Timir Baran, 2Q, 2V, 3B

Ruiko, Watanabe, $2 \mathrm{~N}$

Russo, Pietro, 04

Sabamehr, Ardalan, 2V, 3B

Safaei, Mohsen, OW

Sala, G., 27

Salamone, Salvatore, 29

Sánchez-Romate, Xoan F., 3A

Sansrimahachai, W., $2 \mathrm{U}$

Sarrafi, Aral, 2M

Sbarufatti, Claudio, 3A

Scaccabarozzi, Diego, 3A

Scarpa, F., $1 \mathrm{~L}$

Scarselli, Gennaro, 20, 37

Schaal, Christoph, 00, 1S, 22

Schipf, David, OV

Schumacher, Thomas, 0J

Seo, Dongwoo, 2R, 39

Shen, Yanfeng, $1 \mathrm{Z}$

Shrestha, S., OQ

Shuai, Qi, 2H

Simeoli, Giorgio, 04

Simonini, Alan, $0 Z$

Singh, T., IF

Sinha, Dipen N., 24

Sinha, Sanjiv, $1 \mathrm{~K}$

Slinker, Keith, 06

Sohn, Hoon, IY

Soman, Rohan, 05, 2W

Sorrentino, Luigi, 08

Starovier, Anzhelika, 3H

Staszewski, Wieslaw J., OR, 1U, 23

Sternini, S., 1B

Su, Xiaoshi, OM

Su, Zhongqing, $1 \mathrm{X}$

Subramaniam, Kolluru V. L., 2 I

Sun, Changsen, 2S, 34

Sun, Hu, 2E

Surace, C., 33

Tai, Steffen, 22

Tang, J., $2 \mathrm{H}$

Thostenson, Erik T., OJ

Tirone, M., 33

Toachoodee, M., $2 \mathrm{U}$

Todd, Michael D., 07

Tonelli, Daniel, 2G

Toshiaki, Mizobuchi, 2N

Touchard, Fabienne, 08

Uhl, Tadeusz, OR, 1U, 23

Ureña, Alejandro, 3A

Valavala, Krishna V., IK

Verzobio, Andrea, 2G

Victor, Jared J., 07

Wandowski, Tomasz, OB, 1D, 21

Wang, K. W., 16

Wang, Kai, $1 \mathrm{X}$

Wang, Wei-Chih, OV, 12 
Wang, Yishou, 2E

Wei, Heming, 27

Wei, XU, 2D

Wu, Chun-Wei, 12

Wu, Wen-Jong, OV

Yoo, David, $2 \mathrm{H}$

Yuan, Shenfang, $1 \mathrm{X}$

Zhang, Aijia, 2E

Zhang, Weiting, OF

Zhao, Xuefeng, 2S, 34

Zhou, Li, 32

Zhou, Linren, 38

Zonta, Daniele, $2 \mathrm{G}$

Proc. of SPIE Vol. 10170 1017001-11

Downloaded From: https://www.spiedigitallibrary.org/conference-proceedings-of-spie on 26 Apr 2023 Terms of Use: https://www.spiedigitallibrary.org/terms-of-use 
Proc. of SPIE Vol. 10170 1017001-12 Downloaded From: https://www.spiedigitallibrary.org/conference-proceedings-of-spie on 26 Apr 2023
Terms of Use: https://www.spiedigitallibrary.org/terms-of-use 


\title{
Conference Committee
}

\author{
Symposium Chairs
}

Jayanth N. Kudva, NextGen Aeronautics, Inc. (United States)

Theodoros E. Matikas, University of loannina (Greece)

Symposium Co-chairs

Tribikram Kundu, The University of Arizona (United States)

Gregory W. Reich, Air Force Research Laboratory (United States)

Conference Chair

Tribikram Kundu, The University of Arizona (United States)

Conference Co-chair

Paul Fromme, University College London (United Kingdom)

Conference Program Committee

Hoda Azari, U.S. Dept. of Transportation (United States)

Sourav Banerjee, University of South Carolina (United States)

Yoseph Bar-Cohen, Jet Propulsion Laboratory (United States)

Fu-Kuo Chang, Stanford University (United States)

Anthony J. Croxford, University of Bristol (United Kingdom)

Victor Giurgiutiu, University of South Carolina (United States)

Srinivasan Gopalakrishnan, Indian Institute of Science (India)

Wolfgang Grill, Universität Leipzig (Germany)

Guoliang Huang, University of Missouri (United States)

Xiaoning Jiang, North Carolina State University (United States)

Ajay M. Koshti, NASA Johnson Space Center (United States)

Sridhar Krishnaswamy, Northwestern University (United States)

Francesco Lanza di Scalea, University of California, San Diego (United States)

Zhu Mao, University of Massachusetts Lowell (United States)

Christopher Niezrecki, University of Massachusetts Lowell

(United States)

Wieslaw M. Ostachowicz, The Szewalski Institute of Fluid-Flow Machinery (Poland)

Xinlin Qing, Xiamen University (China)

Henrique L. Reis, University of Illinois at Urbana-Champaign (United States)

Fabrizio Ricci, Università degli Studi di Napoli Federico II (Italy) 
Piervincenzo Rizzo, University of Pittsburgh (United States)

Hoon Sohn, KAIST (Korea, Republic of)

Wieslaw J. Staszewski, AGH University of Science and Technology (Poland)

Zhongqing Su, The Hong Kong Polytechnic University

(Hong Kong, China)

Michael D. Todd, University of California, San Diego (United States)

Tadeusz Uhl, AGH University of Science and Technology (Poland)

Wei-Chih Wang, University of Washington (United States)

Jinkyu Yang, University of Washington (United States)

Lingyu Yu, University of South Carolina (United States)

Andrei N. Zagrai, New Mexico Institute of Mining and Technology (United States)

\section{Session Chairs}

1 Composite Monitoring I

Tribikram Kundu, The University of Arizona (United States)

Paul Fromme, University College London (United Kingdom)

2 Composite Monitoring II

Piervincenzo Rizzo, University of Pittsburgh (United States)

Fabrizio Ricci, Università degli Studi di Napoli Federico II (Italy)

3 Metamaterial I

Guoliang Huang, University of Missouri (United States)

Jinkyu Yang, University of Washington (United States)

$4 \quad$ Metamaterial II

Jinkyu Yang, University of Washington (United States)

Guoliang Huang, University of Missouri (United States)

$5 \quad$ Advancements in Modeling

Sourav Banerjee, University of South Carolina (United States)

Hadi Hafezi, The University of Arizona (United States)

$6 \quad$ Bioinspired SHM and Biomaterial Monitoring

Wei-Chih Wang, University of Washington (United States)

Xiaoning Jiang, North Carolina State University (United States)

$7 \quad$ Real-time Sensing and Testing at Extreme Environments

Tadeusz Uhl, AGH University of Science and Technology (Poland)

Andrei N. Zagrai, New Mexico Institute of Mining and Technology (United States) 
8A Metamaterial III

Fabio Semperlotti, Purdue University (United States)

Mostafa A. Nouh, University at Buffalo (United States)

8B Guided Waves I: Civil Infrastructures Monitoring

Xuan Zhu, University of California, San Diego (United States)

Hoon Sohn, KAIST (Korea, Republic of)

9A Metamaterial IV

Mostafa A. Nouh, University at Buffalo (United States)

Fabio Semperlotti, Purdue University (United States)

9B Guided Waves II: Measurement, Damage Detection, and Scattering

Srinivasan Gopalakrishnan, Indian Institute of Science (India)

See Yeun Chong, University of California, San Diego (United States)

10A Nonlinear Techniques

Tadeusz Stepinski, AGH University of Science and Technology (Poland)

Zhongqing Su, The Hong Kong Polytechnic University

(Hong Kong, China)

10B Modeling for Metamaterial and Guided Waves

Wieslaw M. Ostachowicz, The Szewalski Institute of Fluid-Flow Machinery (Poland)

Lingyu Yu, University of South Carolina (United States)

11A Acoustic Emission

Victor Giurgiutiu, University of South Carolina (United States)

Sridhar Krishnaswamy, Northwestern University (United States)

11B Guided Waves III: Advanced Material Monitoring

Xinlin Qing, Xiamen University (China)

Pawel Malinowski, Institute of Fluid-Flow Machinery (Poland)

12A Civil Infrastructure I: Measurement Optimization and Application

Henrique L. Reis, University of Illinois at Urbana-Champaign (United States)

Ajay M. Koshti, NASA Johnson Space Center (United States)

12B Optical and Thermal Techniques for Civil Infrastructure Monitoring

Christopher Niezrecki, University of Massachusetts Lowell (United States)

Zhu Mao, University of Massachusetts Lowell (United States) 
13A Civil Infrastructure II: Materials and Structures

Paul Fromme, University College London (United Kingdom)

Henrique L. Reis, University of Illinois at Urbana-Champaign

(United States)

13B Emerging and Futuristic Techniques and Issues

Wieslaw M. Ostachowicz, The Szewalski Institute of Fluid-Flow Machinery (Poland)

Anthony J. Croxford, University of Bristol (United Kingdom) 


\section{Introduction}

In the year 2001 the SPIE Conference on Health Monitoring of Structural and Biological Systems brought engineers, materials scientists, medical doctors, and biologists together to exchange their ideas on this important topic. After having a positive experience at that conference, yearly conferences were organized on the same topic and the next one has been planned for the year 2018. Proceedings Volume 10170 contains papers presented at the 2017 conference. Papers presented in the earlier conferences can be found in SPIE Proceedings Volumes 4335 (2001), 4702 (2002), 5047 (2003), 5394 (2004), 5768 (2005), 6177 (2006), 6532 (2007), 6935 (2008), 7295 (2009), 7650 (2010), 7984 (2011), 8348 (2012), 8695 (2013), 9064 (2014), 9438 (2015), and 9805 (2016).

The emphasis of this conference is to recognize that nondestructive sensing, sensor array design, signal acquisition and transmission, signal processing, energy harvesting etc. are integral parts of health monitoring for both structural and biological systems. I believe that biological and physical science communities are learning from one another by coming to this conference and exchanging ideas. Some of the recent advances in the science and technology of health monitoring techniques that go beyond the traditional nondestructive testing for internal flaw detection are presented in these proceedings. New diagnosis, prognosis, and rehabilitation techniques applied to engineering structures made of metal, concrete, and composites, as well as biological systems are presented. The papers published here cover a wide range of technologies. It is hoped that this conference will stimulate further interactions between physical and life science communities resulting in newer development of more innovative techniques for health monitoring applications.

I am thankful to the program committee members, authors, session chairs, and the SPIE staff for putting together this excellent conference.

Tribikram Kundu 
Proc. of SPIE Vol. 10170 1017001-18 Downloaded From: https://www.spiedigitallibrary.org/conference-proceedings-of-spie on 26 Apr 2023
Terms of Use: https://www.spiedigitallibrary.org/terms-of-use 